\title{
THE EXPERIENCE OF THAUMA: COGNITION, RECOGNITION, WONDER AND DISBELIEF
}

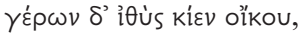

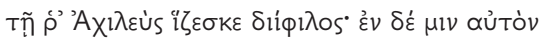

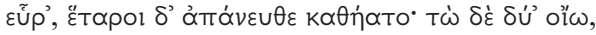

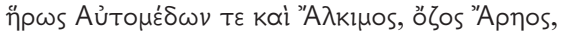

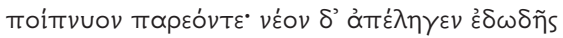

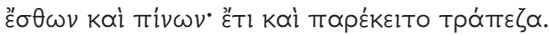

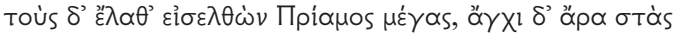

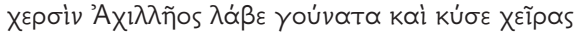

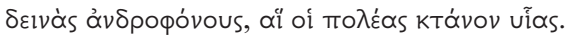

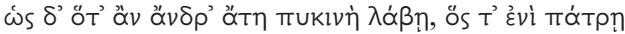

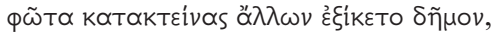

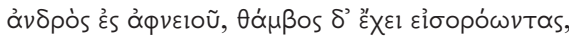

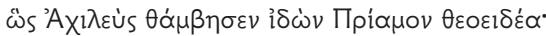

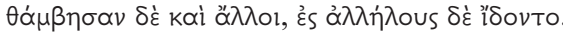

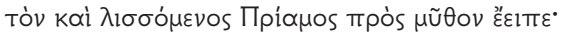

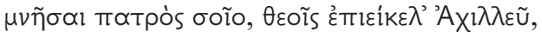

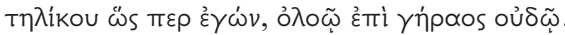

And the old man went straight to the house where Achilles dear to Zeus was accustomed to sit. He found him there, but his companions sat far off; two of them alone, warrior Automedon and Alkimos, scion of Ares, were busily attending to him. And Achilles had just turned away from his food, from eating and drinking, and the table still lay beside him. Unnoticed by them great Priam came in, and then after standing next to him took Achilles' knees in his hands and kissed his hands, the terrible man-slaying hands which had slaughtered many of his sons. And just as when suffocating madness has come over a man, who has killed someone in his own country and comes to the country of other people, to the house of a wealthy man, and wonder takes hold of those who look at him, in this way Achilles wondered seeing godlike Priam, and the others wondered as well, and looked at each other. And Priam entreated him, and said this to him: 'Remember your father, godlike Achilles, of similar age to me, on the deadly threshold of old age'.

Iliad 24.47 I-87 
The climactic meeting of Achilles and Priam in the middle of the Iliad's final book has long been considered one of the most moving episodes in the entire Greek literary tradition. Wrath ( $\mu$ ñvls), the emotion which is held up in the poem's first line as the essential motivation of the Iliad's entire narrative, and which is at the forefront of Achilles' mind from the moment he loses Briseis, finally gives way to pity over the course of this encounter. The emergence of pity as the foremost emotion aroused in Achilles, and by extension in us the audience, has been emphasised by recent critics as perhaps the most essential element in the success of book 24 as a fitting closure to the action of the Iliad as a whole. ${ }^{\text {I }}$ But pity is not the only emotional keynote which this scene explores. Before pity is provoked by Priam's supplicatory actions and words, it is wonder which is thrust to the forefront of our attention. Achilles first marvels at Priam's sudden quasi-epiphanic appearance, but as the scene draws on it becomes clear that this is not the only aspect of their mutual wonder which these lines draw to our attention. For wonder is also one of the predominant emotional responses which the young warrior and the old king feel in each other's presence at the mutual recognition of the similarities which exist between them, as well as an effect of the cognitive realisation that their current situations are perhaps not as diametrically opposed as they might have appeared at first glance. It is precisely the double-edged impact of thauma as both an emotional and cognitive response that this chapter explores in more detail.

Recognition (anagnorisis) is configured from Homer onwards as producing an inherently astonishing effect on both an emotional and cognitive level. Not only is thauma consistently conceived of as an emotional reaction to the recognition that what was initially perceived to be radically 'other' is in some sense uncannily familiar, and vice versa; it is also seen as a sort of catalyst which kickstarts the cognitive processes of realisation and learning

${ }^{1}$ Especially in the influential reading of the Iliad as a poem with pity at its heart which Macleod (I982) I4 puts forth: cf. his thoughts on the place of the final book within Homer's overall conception (p. 8): 'if the description of suffering and the evocation of pity are the very essence of poetry as Homer conceives it, then Book 24 is a proper complement and conclusion to the rest'. 
which potentially ensue as a result of this recognition. By the end of the fifth century BCE the potential impact of the emotional and cognitive effects of thauma are subject to an increasing level of scrutiny. On the one hand, thauma is increasingly seen to play a vital role within the realm of intellectual endeavour as a force which is able to highlight ignorance, provoke curiosity and act as a spur towards the acquisition of new or modified knowledge. But at the same time, it takes on an increasingly ambivalent aspect as the notion that thaumata can be fabricated by humans of their own accord, rather than being produced by and belonging to the natural world or divinely sanctioned by the gods, takes hold. It is in Plato's work that we can most clearly see the culmination of these two responses to thauma: on the one hand, wonder becomes the origin of the newly defined field of 'philosophy' itself, but at the same time it has also become a deeply questionable and potentially distracting effect in the hands of anyone but the 'true' philosopher.

But before returning in the following chapters to the significance of thauma in the newly codified genre of philosophical writing which Plato's work represents, certain aspects of the position of thauma in the intellectual climate of the late fifth and early fourth centuries BCE need to be examined in order to demonstrate how and why responses to thauma and thaumata started to shift over the course of the fifth century BCE. I will begin in this chapter by examining the place of pity and thauma in the meeting between Achilles and Priam in Iliad 24, a scene which has often been read as a precursor of Greek tragedy in its thematic focus and emotional intensity, before turning to Aristotle's later reading in the Poetics of the relationship between thauma and anagnorisis in fifth-century Athenian tragedy. This will be followed by an examination of how these themes work in Euripides' Iphigenia among the Taurians (henceforth IT) and Ion. Throughout the meeting between Achilles and Priam, the constant interplay between nearness and distance, familiarity and unfamiliarity, in both literal and metaphorical terms, contributes to the increasing sense of wonder which both men feel in each other's presence. In the recognition-scenes of tragedy the thauma provoked by this interplay between nearness and distance becomes even clearer, as the unfamiliar can suddenly appear familiar, or the 
familiar oddly unfamiliar. Of the Athenian tragedies which remain to us it is the work of Euripides that probes the potential of thauma and recognition in the theatre most intensely. Euripides' stance towards thauma is particularly illuminating for several reasons. His particular interest in and alignment with the most pressing trends in his contemporary intellectual climate is a topos of criticism on the tragedian, who was already called 'the philosopher of the stage' in antiquity. ${ }^{2}$ By assessing his treatment of recognition and thauma, it becomes possible to discern some of the ways in which wonder fits into contemporary theatrical and intellectual thought. ${ }^{3}$ Furthermore, Euripides' later plays seem to exhibit an intense interest in the workings of recognition, a tragic plot device which is almost always inherently wondrous. The most famous example of this interest is of course in Euripides' Electra (508-84), where he reworks the recognition scene between Electra and Orestes in Aeschylus' Choephori (I64-245). ${ }^{4}$ But as we shall see, several other Euripidean plays are equally concerned with recognition and its wondrous effects.

The power of the tragic recognition scene to provoke wonder, disbelief and questioning of even our most basic assumptions becomes one of Euripides' predominant concerns in his later plays, some of which are set in very unusual locations. Towards the end of the fifth century, Euripides probes the potential of distant settings most intensely in three plays which share certain similarities of theme, plot and setting: IT (c. 4I4 BCE), Helen and Andromeda (both first produced in 4I2 BCE). All three of these

2 The description of Euripides as a 'philosopher of the stage' is first attested at Vitr. De arch. 8 pr. I (Euripides ... quem philosophum Athenienses scaenicum appellaverunt). The first attested uses of this appellation in Greek are found in Athenaeus'

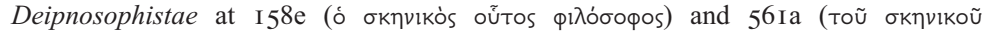

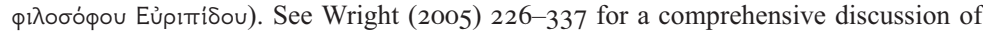
Euripides' designation as 'philosopher of the stage' and the influence of contemporary intellectual trends and philosophical ideas in his 'escape-tragedies' set in distant lands (Helen, IT, Andromeda).

3 On aspects of Euripides' plays which are influenced by and reflective of contemporary intellectual trends more generally, see e.g. Reinhardt (I960) 227-56, Winnington-Ingram (I969) I 27-42, Conacher (I998), Allan (I999-2000) I45-56 and Dunn (2017) 447-67.

4 For recent treatments of the relationship between the recognition-scenes in Aeschylus' Choephori and Euripides' Electra, see e.g. Davies (I998) 389-403, Torrance (20I I) I79-92 and (20I3) I4-33 and Zeitlin (20I2) 36I-78. 
plays begin with endangered female protagonists trapped in distant lands that lie towards the edges of the earth. Iphigenia has been transported from Aulis to the Taurian Chersonese in the north, Helen is residing in Egypt instead of Troy, while Andromeda is bound and awaiting rescue in Ethiopia near the south-western boundary of the known world. ${ }^{5}$ In both IT and Helen, a heroic Greek male arrives in these distant locales and a series of complicated (mis)recognitions soon ensue; the fragmentary state of Andromeda makes it difficult to say much about the play with certainty, but it is clear that Perseus arrives in Ethiopia and encounters Andromeda there, just as Menelaus finds Helen in Egypt and Orestes meets Iphigenia on the Taurian shore.

This chapter examines the connection between recognition and thauma in the IT and shows how both of these themes touch upon another central Euripidean concern in that play: the mythic tradition. After examining these issues the chapter then turns to Euripides' Ion (c. 4I3 BCE), a work which was very probably produced within a few years of IT, Helen and Andromeda. Ion does not at first glance seem easily comparable with these three plays since, far from focusing on the plight of endangered women in distant lands, it concentrates on the life of a young man who dwells in Delphi, the very navel of the Greek world. But when examined more closely, Ion can be seen to share some of the most pressing concerns of other Euripidean plays of this period. Ion may live at the very centre of the world, but he has been abandoned by his absent parents in the same way that Helen, Iphigenia and Andromeda have been left stranded at the edges of the earth, and his own identity turns out to be anything but fixed and wellcentred, as the uncanny familial recognitions (and misrecognitions) of the play gradually reveal. Both IT and Ion are concerned with astonishing familial recognitions in unexpected locations. Both focus on a paradoxical interplay between spatial nearness and distance. This interplay results in thauma, which brings the

5 The Ethiopian setting of Andromeda is situated in the far west, as fr. I45 $\operatorname{Tr} G F$ Kannicht, which describes the monster approaching Andromeda 'from the Atlantic sea'

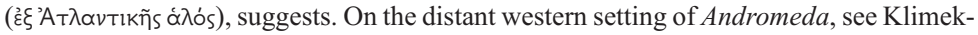
Winter (I993) 259, Wright (2005) I28-9 and Collard and Cropp (2008) I5I n. I. 
veracity and reliability of mythic discourse itself into question while simultaneously mediating between self and other, near and far, and familiar and unfamiliar. But before turning to Euripides, it is worth examining the wonder-inducing meeting between Achilles and Priam more closely.

\section{I Recognition, Realisation and Thauma: The Meeting of Priam and Achilles}

During the climactic meeting between Priam and Achilles in Iliad 24 the wonder provoked by Priam's unexpected arrival provides the main point of contact between the tenor and vehicle of the strangely paradoxical simile that follows even before the marvelling reactions of Achilles and his fellow

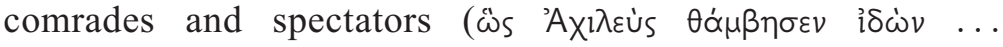

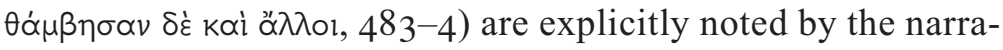
tor. Just as a murderer arriving in a foreign land causes those present to wonder because of the unexpectedness of his arrival and the sense of awe and dread which surrounds a person who has polluted themselves with such a deed, so too does Priam's arrival provoke a natural sense of astonishment. The paradoxes of this simile are multiple. Priam is compared to a murderer, and

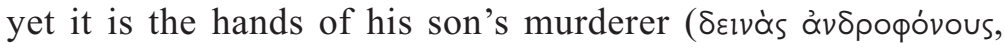
479) that he is kissing; he is like a man in the land of strangers

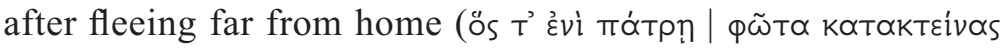

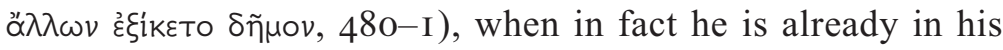
homeland, which is occupied by hostile strangers. The poet dwells on these paradoxes and the resulting wonder they provoke at the very beginning of the meeting between these two enemies to hint towards the ensuing reversals (of Achilles' wrath and, temporarily, of Priam's fortunes) which are about to take place. This also ensures that, in addition to pity, the sense of astonishment apparent at the very opening of this momentous encounter continues to make itself felt in the rest of the episode.

The wonder which arises in this scene has two main causes. The first is the way in which Priam's unseen entry to Achilles' hut and sudden appearance in front of the assembled company is 
deliberately framed as a sort of divine epiphany. ${ }^{6}$ The second is the inherently wondrous impact of processes of recognition and selfrealisation which depend upon an interplay of various kinds of nearness and distance, both literal and metaphorical. I begin with the epiphanic aspect of the passage. As a rule, when a guest visits a host in the Iliad or the Odyssey they are immediately noticed on approach by those present. ${ }^{7}$ Unusually, this is not the case here: Priam's initial entry completely escapes the attention of Achilles

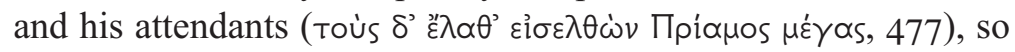
that he is able to creep up on the greatest Achaean warrior com-

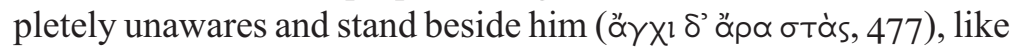
the unexpected arrival of a god beside a mortal. The epithets used to describe Priam as he appears in front of Achilles further reinforce the sense that his sudden manifestation is somehow akin to a divine epiphany. Before the simile, Priam is described as 'great' ( $\mu \varepsilon$ ' $\alpha s, 477)$. This is the only use of this epithet in connection with Priam in the Iliad. It is well-chosen in this context as it both hints at his nobility and emphasises the stunning visual impact of his arrival, since magnitude is an aspect of astonishing visual objects which is often presented as a prime cause of their wondrous effect. ${ }^{8}$ After the impact of the unexpected sight of the 'great' old man has been conveyed by the paradoxical simile about a murderer arriving in a foreign land, Achilles is then explicitly said to wonder at the sight of 'godlike' Priam before

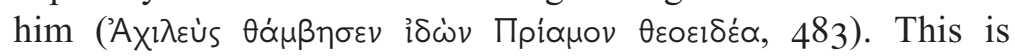
not a redundant epithet at this point in the narrative: Priam is godlike in Achilles' eyes precisely because of the manner of his surprising, unexpected and almost supernatural

${ }^{6}$ On divine epiphanies and thauma, see Chapter 4, sections 3 and 4.

7 See Macleod (I982) I26 and Richardson (I993) 320-I on the departure from the usual Homeric motifs associated with the entrance of guests here. The only real parallel to this sudden and unseen approach in Homer is Odysseus' sudden appearance from his goddess-given cloud during the supplication of Arete at $O d$. 7.I42-5. In this passage it is significant that Odysseus' unseen entrance is heavily aided by Athene: his arrival is thus, like Priam's, a sort of divine epiphany by proxy which provokes a similar reaction

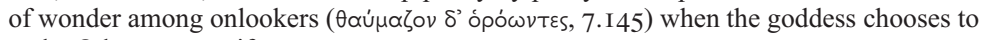
make Odysseus manifest.

${ }^{8}$ Richardson (I993) 322 correctly recognises the weightiness of this epithet at this moment and connects it to Priam's unseen entrance: 'At this momentous point it is appropriate to speak of "mighty Priam" entering unseen, and it helps to prepare for the shock of surprise when he is suddenly seen, present in all his greatness.' 
entrance. ${ }^{9}$ The sudden epiphanic thauma which explicitly opens the encounter between the young Achaean warrior and the Trojan king continues implicitly through the whole scene. It is connected to the sense that the gods are somehow present in the background of this meeting, and that the reversals which ensue as a result of it are divinely sanctioned. This is not surprising given that the meeting has indeed been encouraged and enabled by the gods. In fact, Priam's unusual epiphanic and wonder-provoking appearance has itself already been prefigured by Hermes' similar disguised appearance to him earlier on in the book (24.352-467), an encounter between god and mortal which acted as a catalyst for the old king's successful journey across the empty battlefield towards his younger foe, and which proleptically echoes the encounter between an older and a younger man which will take place once Priam reaches Achilles' dwelling.

Already in this passage, in the very first moments of the meeting between the two enemies, there are hints of the mutually respectful and reciprocal relationship which is about to be established between Priam and Achilles. These relate to the combination of vision, thauma and the implied presence of the gods' power which Priam's epiphanic appearance suggests. In the old man's opening

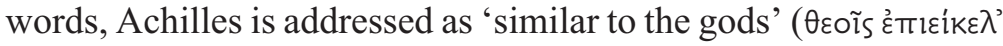

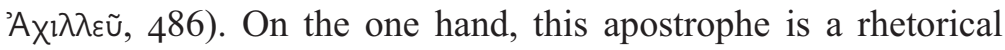
captatio benevolentiae of the most basic kind which aims to flatter Achilles through the common enough comparison of warrior to god - though of course Achilles really is as close to a god as any mortal can be. But at the same time, this epithet gives us a hint of how the scene might be focalised from Priam's perspective: just as Priam seems to approach godhood from Achilles' point of view due to his wondrous ability to appear where he is not expected, from Priam's Achilles has already repeatedly demonstrated his ability to loom large in his enemy's life by snatching away the

9 On the significance of $\theta \varepsilon \circ \varepsilon 1 \delta \varepsilon \dot{\alpha} \alpha$ at Il. 24.483, see Macleod (I982) I27: this epithet is 'more than a generic and decorative one' because '[i]t corresponds to Achilles; and it makes Priam his equal (cf. 629-32): Priam in his turn addresses him as "god-like" (486)'. I would go even further and suggest that this epithet brings out the similarities between the effect of Priam's unseen entrance and the effects of divine epiphanies on their audiences. 
lives of his nearest and dearest. Already then, in the initial glimpses exchanged between the two, we can discern the traces of that explicit and mutual wonder at each other's godlikeness which will increasingly envelope both characters until the point when we reach the end of their initial interaction (24.629-32):

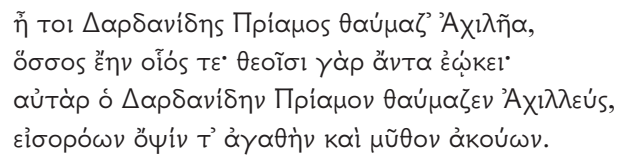

Then indeed Priam son of Dardanus wondered at Achilles, at how big he was and what sort of man he was: for he was like the gods. But Achilles wondered at Priam son of Dardanus, looking upon his noble appearance and hearing his speech.

This mutual wonder at the end of the climactic meeting creates an effect of ring composition; it also emphasises the importance of thauma to the process of mutual recognition and realisation which both Priam and Achilles have undergone. The initial wonder which Achilles feels towards Priam imbues the old man with an aura of divine sanctity and power that finally helps to unlock the young man's sense of pity, and allows this one supplication to be successful, unlike all the many previous supplications of the Iliad, which are immediately and coarsely rejected. ${ }^{\text {IO }}$

The constant interplay of nearness and distance during the central meeting of book 24 is the second central cause of the thauma which this scene as a whole provokes. Achilles' initial astonishment is caused by the literal proximity of someone who has previously been, and should by all rights remain, far away from him. At the start of their meeting, Priam is his enemy and he is the killer of the old man's sons; his own friend Patroclus' death can be attributed to Priam's son Hector and in some sense to Priam personally as the foremost leader of the Trojans. His wonder at Priam's appearance is not only because of its unexpected suddenness but also because the person in front of him, as a result of their enmity, is a manifestation of extreme otherness. And yet it does not take long before both men find they have more in common than

ro Before this moment, every supplication made in the Iliad has been rejected: see Macleod (I982) I 5-I6 for examples. 
first anticipated. The paradoxes and inversions of the opening simile, which casts Priam as a young man who has slaughtered others and found himself in a foreign land - a young man who, like Achilles, has blood on his hands and is unable to return home - provides perhaps the first hint of this. The most striking and wonder-provoking collision of nearness and distance in this passage, however, is surely the way in which Achilles seems to recognise his own father in the father of his enemy. Priam's exhortation to 'remember your father' ( $\mu v \tilde{\eta} \sigma \alpha l$ татрòs бот̃o, 486) explicitly encourages Achilles in some way to recognise his own father's plight, not least because Peleus was both a famous provider for the exiled (most obviously Patroclus), and a notorious exile himself, banished by his father for the murder of his half-brother Phocus. ${ }^{\text {II }}$ Achilles does indeed think of his own father after the old man's opening speech, as the fact that Priam's words

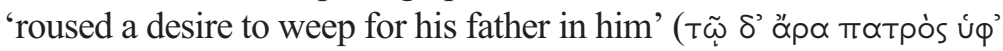

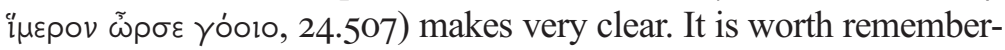
ing as well that Achilles has already configured his own grief for Patroclus as 'like that of a father who wails aloud for his son as he

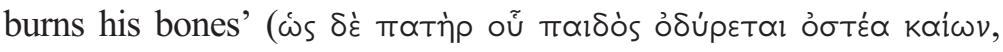
23.222): another unexpected similarity between the two men. By the end of their meeting, both Achilles and Priam have recognised the similarity of their mutual suffering and have discovered that they are closer to one another than they first envisaged. This sort of recognition is not just a renewed understanding of the other, but can be termed a kind of tragic 'realisation' enabled by thauma - a form of recognition which encompasses a discovery of the universality of death, suffering and grief in the human condition and one's place in it. This provokes a renewed sense of wonder at the closeness of an object which was once thought of as being radically distant. ${ }^{{ }^{2}}$

This type of wonder, especially in cases where it is caused by the unexpected recognition or recollection of familial relationships, prefigures some of the uses of thauma in later Greek poetic genres, especially Attic tragedy. For this reason, Homer's attention

II See Heiden (I998) 4-6.

${ }^{12}$ See Rutherford (I982) I59-60 on the tragic realisation which takes place in the scene between Achilles and Priam in Il. 24, especially p. I 47 on 'realisation' as a broader form of anagnorisis which is involved in the attainment of self-knowledge in later Athenian tragedy. 
to the evocation and effects of thauma in the middle of book 24 is another way in which Richardson's assessment of the meeting between Priam and Achilles as 'the most dramatic moment in the whole of the Iliad' seems especially apt. ${ }^{\mathrm{I} 3}$ In the way this episode exposes the uncanny similarities between the two enemies, and in its movement from an initial sense of surprised astonishment (which we might term 'wondering at difference') through to pity, empathy and back to astonishment again (which we might term 'wondering at similarity'), it certainly seems to resemble some of the most moving confrontations between tragic characters in the later dramatic tradition.

Furthermore, the wondrous recognition of the self in the other, and the other in the self, accounts to some extent for the general power and appeal of fifth-century Athenian tragedy to its audience. Often mythical events placed at a spatial and temporal remove from contemporary Athenian life nevertheless show themselves in tragedy to be directly relevant to everyday life. For example, the action may be set over there, in Thebes, in the past, but somehow it applies (often uncomfortably, almost never simply) to the here and now in Athens as well. ${ }^{\mathrm{I}}$ The thauma which this process of recognition involves operates on a cognitive level as a means of forcing an audience to reconsider its own perspective, though the emotional impact of the strange and dislocating effects which this type of unexpected wonder produces is equally significant.

Aristotle well recognised the importance of the dual cognitive and emotional role of wonder in tragedy. Within his wider discussion in the Poetics of the connection of tragic anagnorisis to the creation of pity and fear, he repeatedly emphasises the importance of the astonishment which ensues from unexpected recognitions in tragic theatre. ${ }^{\mathrm{I} 5}$ For Aristotle, the type of wonder aroused by sudden and

13 Richardson (I993) 323.

${ }^{14}$ See e.g. Zeitlin's (I990) I30-67 seminal work on Thebes as a topos in Athenian tragedy.

15 Aristotle first introduces an explicit connection between anagnorisis and ekplexis at Poetics I454a2-4. Here he suggests that a better, 'astonishing sort of recognition'

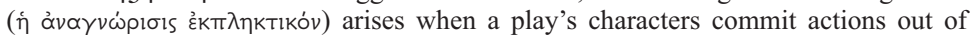
ignorance rather than knowingly and then later recognise the truth of their situation. The impression that ekplexis is the effect which a skilful portrayal of anagnorisis naturally causes is reinforced by Aristotle's later suggestion that 'the best recognition of all is the one which comes out of the events themselves, since astonishment arises through the probable series of events, just as in Sophocles' Oedipus and the Iphigenia [i.e. 
unexpected anagnorisis has both a cognitive and emotional effect on the audience which is intimately connected to a person's supposed ability to learn from mimetic representations. ${ }^{\text {I6 }}$ Aristotle's insistence on the potential cognitive as well as emotional power of the evocation of thauma in the tragic theatre is in line with his views in the Metaphysics (982bI2-2 I) about wonder's status at the beginning of philosophy as a crucial spur to curiosity which causes someone to become aware of their initial ignorance and strive to replace it with knowledge. In that work Aristotle even goes so far as to suggest that 'the philosopher and the lover of myth' - and presumably those who enjoy viewing tragedy can be termed lovers of myth - are naturally the same person, since 'myth is composed of wonders' (o pi $\lambda$ ' $\mu u \theta 0 s$

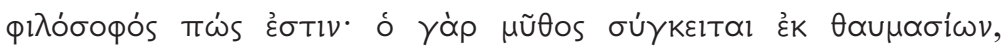
Metaphysics 982 bi $8-19) .{ }^{17}$

In the time that elapsed between Homer's portrayal of the wondrous and pitiful meeting of Achilles and Priam and Aristotle's formulation of the place of thauma in tragic theatre and in philosophical endeavour, wonder has taken on a double-sided and potentially contradictory role in the Greek intellectual tradition. On the one hand, thaumata are the natural material of mythic and other types of discourse, such as ethnographic accounts, which relate to spatially or temporally distant domains. ${ }^{18}$ The spatial or temporal distance of thaumata often causes the reliability and believability of accounts

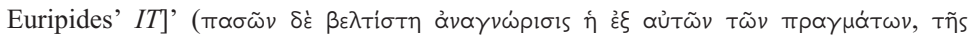

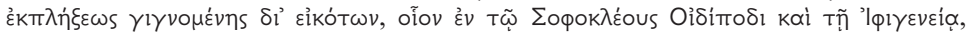
I 455a I6-I 8). Lucas (I968) I 72 argues that the use of the article in $T \tilde{\eta} s \varepsilon \dot{\varepsilon} \pi \lambda \eta \dot{\xi} \xi \varepsilon \omega s$ points to the possibility that Aristotle is here suggesting that ekplexis is caused by the process of anagnorisis in general, rather than solely by the specific 'best type' of anagnorisis mentioned in the previous clause. On ekplexis in the Poetics and its connection to anagnorisis, see Halliwell (20I I) 228-30.

I6 Halliwell (1987) III-I2 well describes the broader conception of the relationship between wonder, recognition and understanding which underpins Aristotle's thoughts about the place of thauma in tragic plots and actions at Poetics I452a4 ff: 'The "sense of wonder" to which he refers is an experience which startles and challenges our capacity to understand what we witness in a play, but it is not one which allows for a deep or final inscrutability: wonder must give way to a recognition of how things do after all cohere "through probability or necessity". Cf. also Cave (I988) 43-6 on the connection Aristotle draws between wonder and recognition in the Poetics.

${ }^{17}$ See Chapter 3, Section 4, for further discussion of this important passage of the Metaphysics.

${ }_{18}$ For more on thauma and the Greek ethnographic tradition, see Chapter 3, Section 3, and Chapter 6, sections I and 2. 
which purport to describe such objects or phenomena to be questioned. This tendency manifests itself in different ways in different genres over the course of the fifth century BCE. For example, in Herodotus' work accounts of marvels must be carefully discussed in relation to the relative weight of personal autopsy and the reliability of hearsay - though the later reception of Herodotus' discussions of

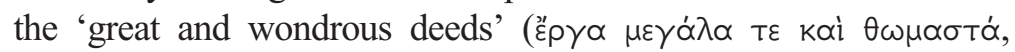
Histories I.I) associated with both Greeks and barbarians in the past and/or in distant lands shows that his handling of marvels was a major contributing factor to the historian's reputation for lies, despite his open consideration of the relative reliability of his various sources. ${ }^{19}$ Elsewhere we begin to see evidence of an increased selfconsciousness about the believability of the mythical tradition in general: perhaps the most famous example being Pindar's First

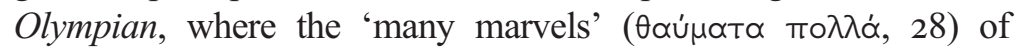
a potentially deceptive tradition of poetic myth are put under the spotlight. It is all of these varying reactions to thauma which Euripides focuses on in his IT, as the next two sections will demonstrate.

\subsection{Marvels at the Margins: Geographical and Mythic Innovation in Euripides' Iphigenia among the Taurians}

It is significant that Euripides seems to have turned his attention to astonishing recognitions in unexpected locations over the course of a few consecutive years, 4I4-4I2 BCE. Both Helen and Andromeda can be securely dated to the City Dionysia of March 4I2, from comments found in Aristophanes' parodic reworking of central scenes from both plays in Thesmophoriazusae (4I I BCE), and from further information found in the scholia to that play and also to Frogs (405 BCE), where Dionysus makes reference to 'reading [Euripides']

I9 See Chapter 6, Section I, for further discussion of some of the earliest evidence for Herodotus' reputation as a liar by the end of the fifth century in Aristophanes' Birds, where it is precisely the language of Herodotean ethnographic thauma which the comedian parodies in order to expose the fantastic and unbelievable nature of the new utopian society of Nephelococcygia. See also Priestley (20I4) 209-22 on the development of the 'Herodotus the liar' theme in the historian's reception in antiquity more generally. 


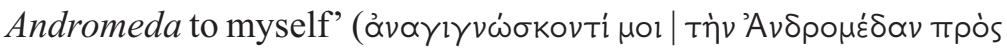
$\varepsilon \dot{\mu} \alpha u t o \dot{v}, 52-3){ }^{20}$ It is not possible to date either IT or Ion with such pinpoint precision, though the current consensus favours placing the first production of both plays in the approximate period 4I4-4I2. ${ }^{2 \mathrm{I}}$ The stylistic and thematic similarities which these plays share have led to suggestions that either IT or Ion might have been the third play in Euripides' trilogy of 4I2, along with Helen and Andromeda, though there is no firm way to confirm or exclude either suggestion. ${ }^{22}$

It is no coincidence that Euripides should have turned his attention to the wondrous and often simultaneously disturbing effects and problems of the near and far over the course of this period. It was a tumultuous time, as the imperial might of Athens pivoted westwards and embarked upon an ambitious invasion of Sicily, an aggressive act which ultimately proved disastrous by the winter of 4I3. Over the course of this crucial period, in which Athenian imperial hopes veered from wildly optimistic to crushingly pessimistic, Euripides' continual, pronounced interest in the

20 At Thesm. I060-I Echo, a character in Euripides' Andromeda, appears and declares that last year in the very same place (presumably the Theatre of Dionysus) she joined with Euripides and aided him in the dramatic contest; cf. $\Sigma$ ad. Thesm. 850, which confirms that Thesmophoriazusae was produced when Helen was still a very recent play. We know that Andromeda and Helen were produced together in the previous year in the same trilogy from $\Sigma$ ad. Thesm. IoI 2, while $\Sigma$ ad. Ran. 53 confirms that Andromeda was produced in the eighth year before Frogs, a play we know was performed at the Lenaia in 405. This gives a date (with inclusive counting) of 4I3/I 2 for Helen and Andromeda and 4I2/I I for Thesmophoriazusae: further evidence from Aristophanes' play supports a date of 4I I (see Austin and Olson (2004) xxxiii-vi for full discussion).

${ }^{21}$ In his edition, Diggle (I98 Ia) 242, 306 suggests a date of c. 4I 4 for IT and c. 4I 3 for Ion. See Kyriakou (2006) 39-4I on the IT's possible date range; cf. Parker (20 I6) lxxvi-lxxx on the metrical basis for dating IT to c. 4I4. For a more speculative approach to the metrical dating of $I T$ which argues that the play is a pre-4I 5 work, see Marshall (2009) I 4 I -56 and (20I4) I I-I2. For summaries of the more complicated issues surrounding the precise dating of the Ion, see Martin (2018) 24-32 and Gibert (20I9) 2-4.

22 Wright (2005) 44-55 argues at length for a Euripidean 'escape-trilogy' in 4I2 BCE consisting of Helen, Andromeda and IT; this position is also supported by Jordan (2006) 20. See also Wright (2006) 23-48 for the suggestion that Helen, Andromeda, IT and Cyclops were performed as a tetralogy in 4I2 BCE. Wright (2005) 50 supports his argument for an 'escape-trilogy' in 4I2 with the suggestion that the final scenes of Aristophanes' Thesmophoriazusae subtly parody aspects of Euripides' play, just as early scenes had contained more obvious parodic references to Helen and Andromeda. For similar suggestions about potential references to the $I T$ at the end of Thesmophoriazusae, see Hall (I989) 52 n. 7I, Bobrick (I99I) 67-76, Sommerstein (I994) 237, Cropp (2000) 62 and Kosak (2017) 2I5. For an alternate possibility, a trilogy consisting of Helen, Andromeda and Ion in 4I 2 BCE, see Zacharia (2003) 3-7. 
relationship of the Hellenic centre of the world to its more distant and potentially astonishing peripheries reflects, in no simple manner, contemporary concerns about the relationship of Athens to other places and societies which at one moment appear very different, and at another similar.

The complicated relationship between centre and periphery is one of the concerns which lies at the heart of Euripides' IT. It is no coincidence that this play also thrusts questions concerning the nature of wonder and its effects to the forefront of the audience's attention. Language connected to thauma appears more frequently in the $I T$ than in any other surviving Euripidean work. ${ }^{23}$ Throughout the play Euripides consistently emphasises the inherent wonder of distant and exotic geographical locations through the repeated appearance of thauma and its effects. By the end of the prologue, the unusual and potentially wondrous nature of the play's geographical setting, and its treatment of conventional mythical tradition, has already become self-evident to the audience. Usually the immediate geographical frame of a Euripidean play is made clear in the first few opening lines, but it is not until Iphigenia reveals in line thirty of her opening speech that she is

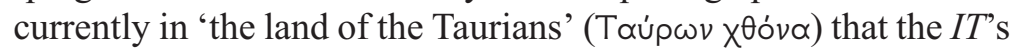
setting is revealed - unprecedentedly late for a Euripidean prologue. ${ }^{24}$ Before we reach this point, however, Iphigenia begins her speech by focusing first on Aulis, the location most intimately connected to her past fate $(\mathrm{I}-9)$ :

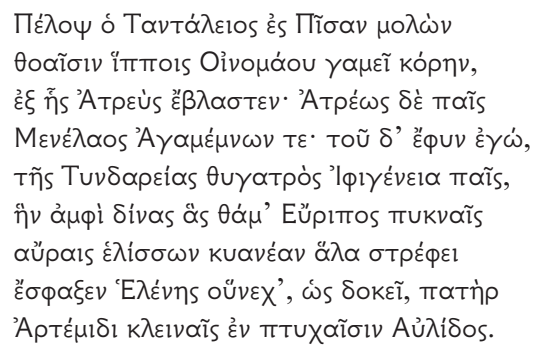

With swift horses, Pelops the son of Tantalus, after going into Pisa, wedded the daughter of Oenomaus who gave birth to Atreus. And Menelaus and Agamemnon

23 See Budelmann (20I9) 289-304 on the prevalence of thauma in IT.

24 Wright (2005) I 29. 
were Atreus' children. From Agamemnon I was born, Iphigenia, the child of the daughter of Tyndareus. Near the eddies which the Euripus with numerous breezes often turns about, making the dark-blue sea roll, my father - so it's claimed - for the sake of Helen sacrificed me to Artemis, in the famous mountain clefts of Aulis.

The delay before the revelation that Iphigenia is in fact no longer in Greece at all allows the audience's geographical expectations to be manipulated. Iphigenia focuses at the very beginning of the prologue on the idea of swift movement and travel from one location to another, not only with respect to her own swift dislocation from the famous clefts of Aulis, which she describes at length before revealing her current location, but also by picking out the episode in her own ancestral history which is most strongly related to the idea of travel: Pelops' journey to Pisa for his famous chariot race (I-2). The connection between geographical dislocation and mythical innovation, and the surprising effects which ensue from the combination of these two factors, is in this way made immediately apparent from the play's opening lines.

Euripides certainly did not invent the story of Iphigenia's presence in the Taurian land wholesale, as Herodotus' description of Scythia and other northern lands in book four of the Histories demonstrates. In Herodotus' account, however, Iphigenia herself is not said to have carried out sacrifices of Greeks washed up on the shore while she was among the Taurians: instead, 'the Taurians themselves say that Iphigenia the daughter of Agamemnon is the deity to whom they make

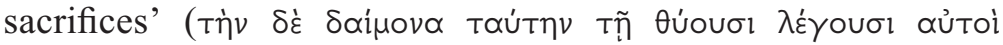

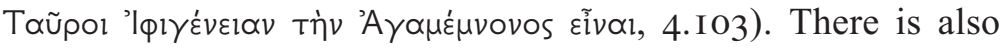
one other play we know about which may have focused on Iphigenia's presence among the Taurians. This is Sophocles' Chryses (frs. 726-9 TrGF Radt). The play possibly depicted the events which occurred after Orestes and Iphigenia fled from the north with a statue of Artemis in tow and the Taurian king Thoas in pursuit. But even if we accept that Sophocles' play focused on this later stage of the escape and the fragmentary remains do not make the events of the 
plot at all clear - the action of Chryses is certainly not set in the far-off land of the Taurians. ${ }^{25}$

The precise location of the distant Taurian territory which Iphigenia and Orestes find themselves inhabiting in Euripides' play was itself a matter of dispute in the fifth century, though it seems to be located somewhere towards the north-eastern edges of the known world, with the Taurians themselves conceived of as a sort of 'semi-mythical' race. ${ }^{26}$ This setting is certainly unusual, if not unique, for a tragedy, as is the placement of both Iphigenia and Orestes in the Taurian land. In fact, it is highly probable that Orestes' rescue of his sister and the Taurian statue of Artemis is a mythical innovation on the part of Euripides, who seems to combine accounts of Iphigenia's escape from Aulis and removal to the far north-eastern edges of the world with Orestes' famous wanderings in order to depict a novel and unexpected familial recognition in an unfamiliar setting. ${ }^{27}$

Over the course of the play various questions about the novelty of myth and the general reliability of the mythical tradition - in both its previous incarnations in the poetry of the past, and in its present Euripidean form - become some of the IT's most pressing and self-conscious concerns. Euripides lays the groundwork of this incessant questioning from the play's first word: Pelops. Putting the name of Iphigenia's somewhat dubious ancestor into

25 The Roman Republican tragedian Pacuvius produced a play entitled Chryses which may be based on the plot of Sophocles' Chryses (see Warmington I936: I92-209). Its remaining fragments suggest that the plot follows the version of the story concerning the aftermath of Iphigenia and Orestes' escape which is related by Hyginus (Fabulae I 20-I). He tells us that after fleeing from the Taurian land with the Artemis statue, the siblings arrive at Sminthe (location unknown, but probably in the Troad), where Chryses, the child of Agamemnon and Chryseis, helps his newly-discovered halfbrother Orestes to kill the pursuing Taurians. Iphigenia, Orestes and Chryses then go to Mycenae together with the statue of Artemis. On this version of the myth and its possible relation to Sophocles' Chryses, as well as other possible versions of the story involving Chryses, Orestes and Iphigenia, see e.g. Wilamowitz (I883) 257-8, LloydJones (I996) 340-3 and Slater (2000) 3I5-I6. A probable allusion to Sophocles' Chryses in Aristophanes' Birds (see $\Sigma$ ad. Av. I240) suggests a terminus ante quem of 4I4 BCE for Sophocles' play, meaning that his Chryses may predate Euripides' IT, though this is by no means certain: on these issues, see Marshall (2009) I4I-56.

${ }^{26}$ See Hall (I987) 427-33 on Euripides' conception of the location of the Taurians in the IT. On ancient confusion over the identity and location of the Taurians, see Cropp (2000) 48 and Hall (20I2) 66.

27 On Euripides' probable mythical innovations in the IT, see e.g. Wright (2005) I I 3 -I5, O'Brien (I 988) 98, Zeitlin (2OI I) 45I and Burnett (I97I) 48, 73-5. 
her mouth as her very first word is not a thoughtless detail on Euripides' part. Throughout the play Pelops' grisly fate at the hands of his father Tantalus, as well as his own sometimes morally questionable actions, are repeatedly called to mind with special reference to Iphigenia's own position as a Tantalid who now has a very special connection to human sacrifice, since Pelops' past parallels Iphigenia's own situation in one fundamental way: both were involved in a form of failed sacrifice at the hands of their own fathers. ${ }^{28}$ The importance of Pelops for Iphigenia's own thinking about her unexpected position in the Taurian land is made clear not long after the prologue. Here Iphigenia ponders the supposed fate of her ancestor by questioning the received accounts of the mythical tradition concerning Tantalus' supposed gory banquet for the gods $(380-9 \mathrm{I})$ :

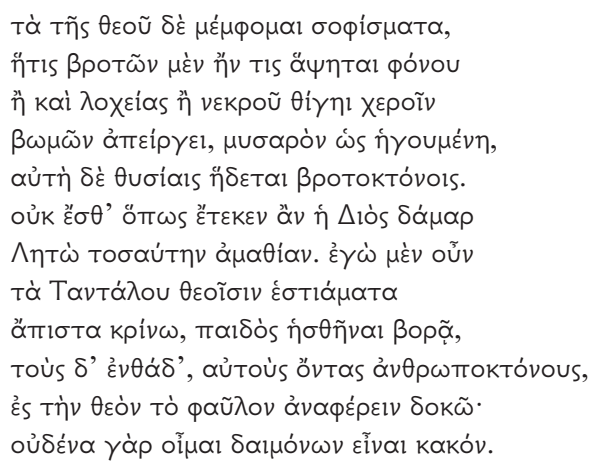

But I censure the clever contrivances of the goddess. For any mortal who has come into contact with slaughter or who touches childbirth or a corpse with his hand, she [i.e. Artemis] keeps away from her altars, thinking that he is polluted. But she herself delights in man-slaying sacrifices! It is not possible that Leto, the consort of Zeus, gave birth to such great stupidity. But no: Tantalus' banquet for the gods, that they enjoyed eating a child - that I judge to be unbelievable. Instead I think that the people who live here, who are themselves man-slaughterers, attribute their own low deed to the goddess. For I believe that no god is wicked.

${ }^{28}$ The significance of Pelops in the $I T$ is generally acknowledged, but the degree to which he can be seen as a model for any single character in particular is debated. Unlike Sansone (I975) and O'Brien (I988), Kyriakou (2006) denies that there is an overall similarity between the escape plot of the $I T$ and the escape of Pelops and Hippodameia from Oenomaus, but agrees that there is an affinity between Iphigenia and Pelops in particular throughout the play, since his connection to (potentially failed) sacrifices is strong (see esp. I2-I3, 276); cf. also Hartigan (I99I) 90. 
This moment is a crucial one in the action of the $I T$, since Iphigenia has been informed of the arrival of Greek strangers on the shore and is beginning to steel herself for her part in the sacrifice, unaware that her brother is among those newlyarrived men. In this passage Iphigenia refuses to ascribe a lust for human sacrifice to the goddess Artemis herself, blaming instead the bloodthirsty Taurians for the supposed necessity of the planned slaughter. A key part of Iphigenia's argument about the nature of Artemis is that the story that her ancestor Tantalus sacrificed and served his son Pelops to the gods is completely 'unbelievable' (åmıт $)$. The thrust of Iphigenia's argument seems to be that Artemis cannot be desirous of human sacrifices from the Taurians because the human sacrifice element of the Tantalus episode itself cannot possibly have happened. These lines, however, have long raised questions over what precisely it is in the Tantalus episode that Iphigenia is judging to be incredible. Is she denying that Tantalus' feast ever took place? Or that even if the feast did take place, the gods certainly did not eat Pelops? Or that even if the feast took place, and the gods ate Pelops, they did not enjoy it? ${ }^{29}$

As it turns out, Iphigenia's declaration at this point in the IT has a very specific antecedent which is also concerned with this supposed failed sacrifice: Pindar's first Olympian. ${ }^{30}$ The use of

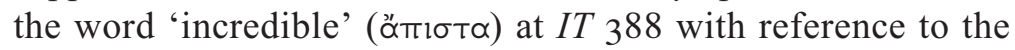
feast of Tantalus specifically recalls lines 25-40 of Pindar's poem, where the well-known account of Tantalus' crime is completely rejected, first with the seeming denial of Pelops' dismemberment and subsequent acquisition of an ivory shoulder as something untrue (28-9):

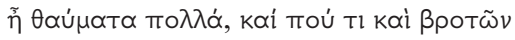

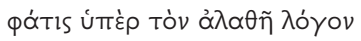

29 Burnett (I97I) 63-4 sees this as a simple case of Iphigenia clearing Tantalus' name 'with her explicit repudiation of his banquet', but there is more ambiguity involved than this. For the various possible interpretations of these lines, see Sansone (I975) 288-9 and Kyriakou (2006) I43-5.

30 Platnauer (I938) 93 notes that $\mathrm{Ol}$. I.35 ff. is a relevant comparison here, while Whitman (I974) Io goes further and suggests that IT 380-9I contains an 'echo of Pindar's First Olympian Ode'. Wolff (I992) 3IO n. 5 and Parker (20I6) I42-3 suggest that Iphigenia's version here explicitly recalls Pindar's $\mathrm{Ol}$. I.36-53. 


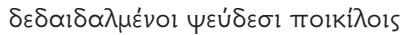 \\ $\dot{\varepsilon} \xi \propto \pi \propto T \tilde{\omega} \nu \tau l \mu \tilde{\theta} \theta 0 l$.}

Yes, truly, marvels are many, and even, I suppose, what mortals say too (that is, stories elaborated above the true account with variegated lies) deceives us.

Pindar goes on to claim that Charis (Grace), is the specific cause that makes the unbelievable believable in such cases $(30-5)$ :

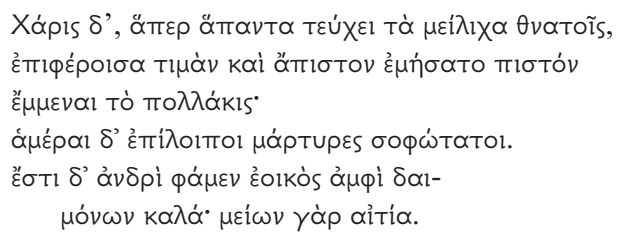

But Grace, who fashions all gentle things for mortal men, through bestowing honour, contrives to make even the unbelievable believable most of the time. But future days are wisest witnesses. It is right for a man to speak well of the gods: the blame is less.

After this, Pindar purports to present the true version of the myth one which does not attribute the evil of eating human flesh to the gods $(36-40)$ :

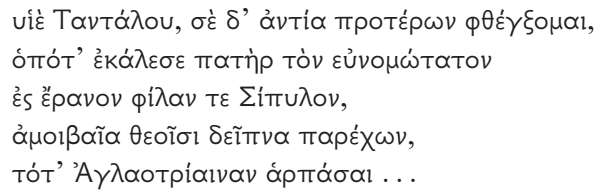

Son of Tantalus, contrary to tradition I will say of you that when your father invited the gods to that most well-ordered feast and to his dear Sipylus, providing to the gods a feast in return for previous hospitality, then the god with the shining trident seized you ...

In the IT, Iphigenia's rejection of the report of Tantalus' feast similarly echoes Pindar's reluctance to attribute deeds to the gods which may force him to speak ill of them. Furthermore, Pindar's rejection of the well-known version of Pelops' fate anticipates Euripides' own practice in this play: previous versions of myth are rejected because of their potential to cause wonder and thereby provoke questions of belief and disbelief, while innovative new versions of mythic stories which seem in some sense to correct the previously dominant versions are presented as 


\subsection{Wonders beyond Mythoi}

authoritative and truthful. Although it seems that wonder is an obvious response to the more unbelievable aspects of a given mythical story, there is also a suggestion - both in Olympian I and in the $I T$ - that even the seemingly believable version of any given account only succeeds in substituting wonders of its own for the discredited wonders of the previous, rejected variant of the tale. ${ }^{3 \mathrm{I}}$ It is this potentially problematic aspect of mythic discourse which Euripides thrusts into the spotlight in the recognition scene of the $I T$ in a starker form than in any other scene in his surviving plays.

\subsection{Wonders beyond Mythoi: Recognition and Thauma in Euripides' Iphigenia among the Taurians}

The IT's prolonged and surprising recognition scene (636-90I) goes on to reinforce the sense that the supposed 'real world' of the action presented in the theatre is just as wondrous and unbelievable as the version of Pelops' story which Iphigenia objected to so vehemently earlier in the play. In antiquity the fact that the action of the play is completely dominated by Euripides' complicated handling of the recognition theme is noticed by Aristotle, who holds up the IT in the Poetics as one of the two tragedies which deserve to be admired most for their treatment and handling of tragic anagnorisis (the other being Sophocles' Oedipus Tyrannus). ${ }^{32}$ Aristotle's admiration for Euripides' treatment of anagnorisis in this play is related to the sheer length of the emotionally heightened recognition scene between Iphigenia and Orestes in which two separate recognitions are portrayed in two separate ways. Orestes first realises that the Greek-speaking priestess on the Taurian shore is actually his sister after a letter is read

3I On the way in which the version of Pelops' story favoured by Pindar can itself be viewed only as a different type of thauma as opposed to a complete banishment of the thaumatic, see Howie (I983) I90 and Bundy (I986) 9.

32 See Poet. I455aI6-2 I; cf. I452a32-b7 and I454a3-7. In line with general critical responses to both plays modern critics and scholars have tended to lavish their attention on Aristotle's admiration for Sophocles' $O T$ while almost completely neglecting his praise for Euripides' IT: see Belfiore (I992) 359-77 and White (I992) 22 I-40 on reasons for Aristotle's intense interest in the $I T$, despite the play's relative lack of appeal to modern critics and audiences. 
out loud, a device which Aristotle thought especially skilful and wonder-inducing because of the fact that Euripides manages to insert this recognition token naturally into the plot. ${ }^{33}$ Iphigenia then comes, by alternate means, to realise that one of the shipwrecked Greek travellers is in fact her own brother when she questions Orestes about items relating to their youth in Argos about which only her brother could know (798-826), culminating with a final piece of information relating to the siblings' grandfather Pelops which forces Iphigenia to believe what initially seemed to be unbelievable.

Orestes' recognition of his sister begins to take shape from line 636 onwards. After learning from a conversation between Orestes and Pylades that her brother is actually alive, Iphigenia, not realising that Orestes is one of the two strangers in front of her, decides to send a writing tablet home to Argos, where she thinks he is now located. Orestes and Pylades realise who Iphigenia is after she returns with the writing tablet and decides to recite its contents aloud for the two strangers to hear and remember as a precaution in case of the physical loss of the tablet and its message on the long sea journey home (759-87). Orestes' initial recognition of his sister emphasises the wonder and disbelief which this realisation causes $(793-7)$ :

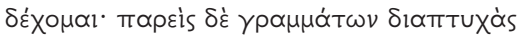

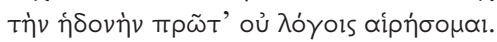

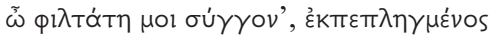

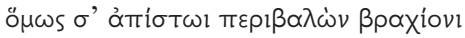

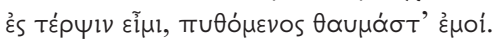

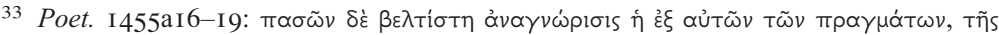

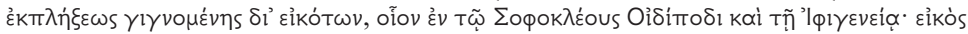

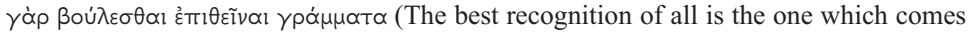
out of the events themselves, since astonishment arises through the probable series of events, just as in Sophocles' Oedipus and the Iphigenia [i.e. Euripides' IT]; for desiring to despatch a letter is probable). Aristotle has also alluded to the belief that only events or actions which seem probable and convincingly believable are able to cause the greatest thauma in audiences earlier in the Poetics (I452a5-II), when he notes that even when it comes to unexpected events, 'the most wondrous of those things that

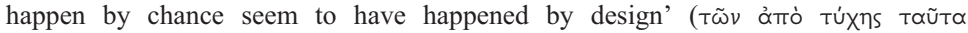

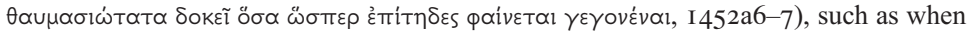
a statue of Mitys falls purely by chance but nevertheless kills Mitys' murderer as if this were an intended outcome. 


\subsection{Wonders beyond Mythoi}

I accept it. But leaving aside the folding leaves of the letter, I shall choose first pleasure without words. O sister dearest to me, though I am astonished, nevertheless, embracing you with disbelieving arm, I shall come to delight, having learnt things which are wondrous to me.

The utter astonishment which Orestes feels on the recognition of a familiar relative in an unfamiliar location is soon paralleled by Iphigenia's own response once she overcomes her disbelief and accepts that the Greek stranger who has washed up on the Taurian shore is actually her brother. But before Iphigenia can come to recognise that this is the case, an elaborately-structured stichomythia takes place in which Pelops, the relative whose situation most closely echoes Iphigenia's own circumstances, plays a crucial part (806-9):

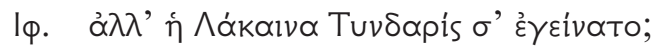

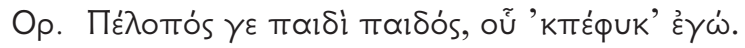

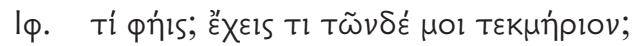

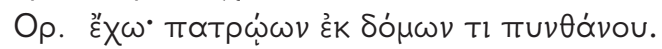

IPHIGENIA: But did the Spartan woman, the daughter of Tyndareus, bear you?

Orestes: Indeed, she did: to the child of Pelops' child, whose son I am.

IPHIGENIA: What are you saying? Do you have some proof of this for me?

ORESTES: I have it. Inquire about something from our father's house.

The first two proofs - the story of the golden ram of Atreus and Thyestes told through Iphigenia's weaving, and the report of Iphigenia's Aulis bath and the removal of a lock of hair - are known to Orestes through 'hearsay' (ảkoñn, 8II) alone, from his other sister, Electra. The third piece of evidence - the one which actually clinches the successful recognition - is the only one which is thoroughly autoptic, and thereby presumably more reliable, than the rest (822-6):

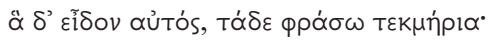

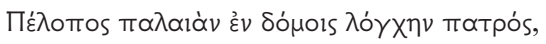

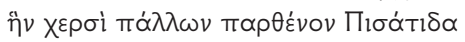




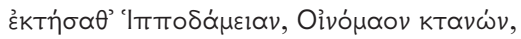

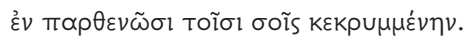

But the things which I myself have seen, these proofs I will tell to you: [I have seen] hidden in your maiden bedroom the ancient spear of Pelops in the house of our father, the one which he brandished in his hands when he obtained the maiden from Pisa, Hippodameia, killing Oenomaus.

The link between Iphigenia and Pelops is thus strengthened yet again by the mention of this important ancestral object, which simultaneously becomes a catalyst for the realisation that the two siblings are intimately connected, despite the previous distance which existed between them. Moreover, this final moment of recognition involving Pelops' spear leads to a recapitulation of the themes surrounding Iphigenia's discussion of the possibility of Tantalus' banquet for the gods, with the link between the unbelievable 'myth' and thauma once again highlighted. The idea that the wonder created by the recognition transgresses the very boundaries of what can be said in words is picked up again by Iphigenia's response at the moment she recognises her brother (838-40):

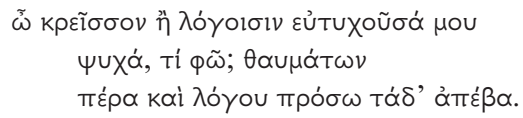

O my soul, more good-fortuned than words can tell! What shall I say? Beyond wonders and beyond words these events have turned out!

These words echo Orestes' recognition (793-7), quoted in full above. The importance of the meeting's unexpected geographical location helps to create an additional sense of wonder at this moment of anagnorisis. Throughout the IT, Euripides plays with familiar tropes of recognition in unfamiliar geographical locations to probe the nature and boundaries of thauma and its relation to belief and disbelief. ${ }^{34}$ The traditional antitheses between familiar, unremarkable objects or events, and unfamiliar, wonder-inducing objects or events are continually inverted. The importance of the language of thauma to the impact of the recognition scene is further reinforced by the very end of the siblings' reunion, where

34 See further Budelmann (20I9) 296-9 on the language of (dis)belief in relation to thauma in the $I T$. 


\subsection{Wonders beyond Mythoi}

we find the chorus offering a brief comment which picks up on the thaumatic language used by Orestes and Iphigenia throughout the recognition-scene (900-I):

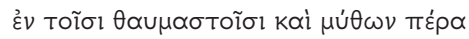

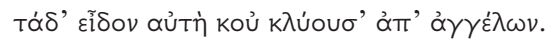

These events are wonders and beyond myths! And I myself have seen them, rather than hearing them from messengers!

The emphasis on the fact that these sights have really been seen by the chorus and not only heard by report has a further resonance here, as it reflects the audience's own experience of having witnessed the recognition scene immediately beforehand. The audience's response is also reflected at the end of the play in the reaction of Thoas, the hostile barbarian king of the Taurians, to the escape of Iphigenia and Orestes (I3 I7-24):

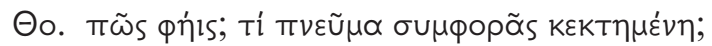

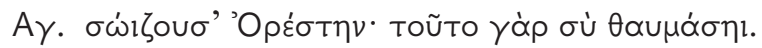

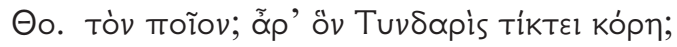

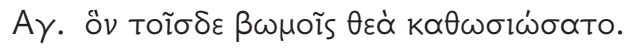

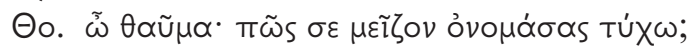

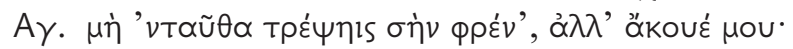

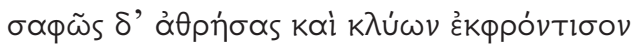

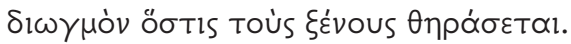

ThoAs: What are you saying? What favourable gust of good luck did she obtain?

Messenger: She was rescuing Orestes. You will wonder at that!

ThoAs: What Orestes? The one the daughter of Tyndareus bore?

Messenger: The one whom the goddess consecrated for herself at these altars.

ThoAs: $\quad$ O wonder! How can I call you by a greater name and hit the mark ${ }^{35}$

35 Line I32 I has long troubled commentators uncomfortable with the idea of a vocative address to thauma. See Diggle (I98Ib) 89-9I for possible emendations, and Kyriakou (2006) 4I 8-I9 for a good summary of the various interpretations of this line. Markland's suggestion that $\mu \varepsilon^{\prime} \zeta o v$ should read $\mu \varepsilon$ ío $v$ is defended by Diggle but rightly rejected by 
MESSENGER: Don't turn your mind in that direction: listen to me instead! After observing clearly and hearing, think out a means of pursuit to hunt down the strangers.

The chorus' final judgement that the recognitions which they have just witnessed are 'beyond wonders', and Thoas' astonished response to the improbable events which have just taken place before his eyes, both raise questions about what the appropriate response to the mimetic power of drama - and to mythical stories in general - should be. Throughout the IT Euripides thus plays with familiar tropes of recognition in unfamiliar geographical locations to probe the power of tragic thauma on the audience of the theatre itself.

\subsection{Marvels at the Centre: Delphi, Athens and Thauma in Euripides' Ion}

In the action of Euripides' Ion, thauma is similarly presented as a natural reaction to the inversion of the familiar and the unfamiliar. In stark contrast to the IT, Ion is set at the very centre of the Hellenic world: the omphalos at Delphi. Throughout the action there is a constant interplay between Delphi and Athens, the location which would have seemed closest of all to the original audience. As the play draws on, each location appears to be sometimes near at hand, sometimes distant. ${ }^{36}$ By the end of the play the manipulation of the near and the far exposes the uncanny familiarity of unexpected events right at the centre of the world. Thauma is again manipulated by Euripides in ways which intertwine with this dynamic. The centrality of this interplay between near and far is made most clear by Ion's response to his unexpected recognition of Xouthos, who claims (falsely) to be his father $(585-6)$ :

Cropp (I997) 40-I and (2000) 254, who notes that the rhetorical point of this question is the suggestion that the very term and concept of wonder is insufficient to express the enormity of the events just described and witnessed in the theatre. See also Parker (2016) 322-3 for discussion of reasons why this vocative address to thauma should be maintained.

${ }^{36}$ On the constant interplay between the words $\varepsilon \dot{v} \theta \dot{\alpha} \delta \varepsilon$ (here) and $\varepsilon \kappa \varepsilon \tilde{l}$ (there) in the Ion (e.g. at 24, 25I, 384-5, 645, I 278), see Loraux (I990) I 77. On the play's near/far dynamic and its connection to Athens and Delphi, see Zacharia (2003) 22 and Griffiths (2017) 236. 
The appearance of things at a distance is not the same as when they are seen close up.

These words - which anticipate later Platonic conceptions of the relationship between thauma and perspective - have been taken as a programmatic statement about the action of the play as a whole. ${ }^{37}$ Certainly, this antithesis between the near and the far becomes one of the central structuring principles of Euripides' play. In some respects, the unique position of Delphi at the centre of the world suggests that the appearance of unfamiliar marvels in this location is unlikely if the customary geographical expectation that the further away from the Greek centre one travels, the more likely one is to encounter thaumata is adhered to rigidly. But in another, more paradoxical sense, the idea of Delphi as the rightful domain of the marvellous is not as bizarre as it might at first seem: its very status as the dead centre of the entire known world lends it a remarkable power of its own, symbolised not least by the wondrous nature of the omphalos itself - as Hesiod had already made clear with his description of the placement of the Delphic stone itself as ‘a wonder for mortal men' ( $\theta \alpha$ ũ $\mu \alpha \theta v \eta$ тог̃ Theog. 500).

Ion's two lengthy ekphrases reinforce the sense that in this play wonders lurk at the very centre of the world as opposed to the edges of the earth. The first ekphrasis (I84-2 I8) consists of the chorus' description of the images on the temple at Delphi. Despite the familiarity of the images the chorus is viewing, the recognition of these scenes is still able to provoke a marvelling response (190-200):

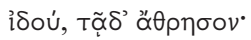

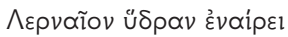

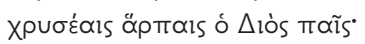

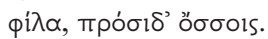

37 See Lee (I997) 226 and Gibert (2019) 2 I 7 on the programmatic nature of this statement in the Ion. See Chapter 7, Section 3, for discussion of Platonic configurations of this sentiment and its connection with thauma and its effects. 


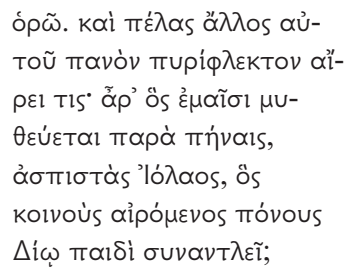

Look, observe this! The son of Zeus slays the Lernaian hydra with a golden sickle. Friend, look over here with your eyes.

I see. And near him another man raises a torch blazing with fire. Is it the man whose story is told at my loom, the shield-fighter Iolaus, who takes up common labours with the son of Zeus and endures them with him to the bitter end?

There are striking similarities between the chorus' viewing of the temple at the beginning of the play, and the later ekphrasis of the tent adorned with thaumata which Ion constructs, and within which he almost meets his end at his own mother's hands (I I4I-5):

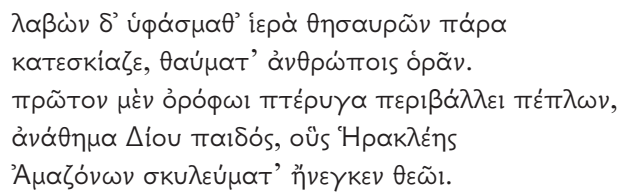

And after taking the sacred tapestries from the storeroom he began to spread them as coverings, marvels for men to see. First, he threw over a covering of robes as a roof, an offering from Zeus' son, which Heracles offered to the god as spoils from the Amazons.

The constant focus throughout the play on external, monstrous dangers points out the irony of Ion's real situation: that it is not dangers from without which are a threat to him, but his own family. In fact, it is the failure to recognise what is truly familiar which motivates the central action of the play. ${ }^{38}$

On the other hand, although Ion and Creusa do not explicitly recognise each other immediately, there are hints of an uncanny feeling of kinship from their very first meeting. The opening interaction between them reveals an implicit relationship between

$3^{8}$ See Lee (I997) 22; cf. Danek (200I) 55.

I34 
the two in a way which is completely lacking in Ion's meetings with Xouthos. For Ion, his Athenian mother is immediately an object of wonder who is able to catch his attention. This is apparent at $247-8$, when Ion is astonished by Creusa's tears, which for her shows his good upbringing:

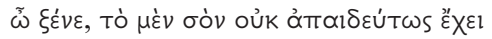

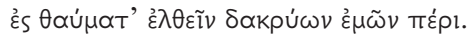

O stranger, your behaviour - this coming to wonder at my tears - shows that you are not uneducated.

In contrast to Ion's cold and non-committal response to the revelation that Xouthos is his supposed father, mother and son seem to share an immediate concern for one another, suggesting elements of a wondrous subconscious anagnorisis. ${ }^{39}$ On closer inspection, we find that throughout Ion the distant is much closer than it might at first glance seem.

One other strand of imagery contributes powerfully to the Ion's representation of the multiple intersections between near and far, familiar and unfamiliar. Birds, always potential signifiers of the ability to travel to distant places, take on a particular significance in relation to Ion himself. ${ }^{40} \mathrm{He}$ mentions three birds during his temple-cleaning monody: first an eagle,

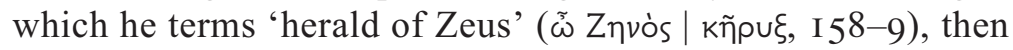
a swan (Kúkvos, I62), and finally a more ambiguous 'new bird'

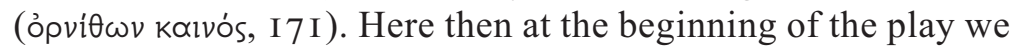
find a mixture of familiar and unfamiliar birds which cause the first of a series of unexpected avian intrusions into the play's action - intrusions which will eventually culminate in the recognition of mother and son. ${ }^{4 \mathrm{I}}$ The connection between bird imagery and Ion is strengthened when Ion himself is described as a 'new son' (ó kalvós... yóvos) (I 202) at the point towards the

39 Lee (I997) I87. See also lines 262-3, where Creusa's Athenian lineage fills Ion with an

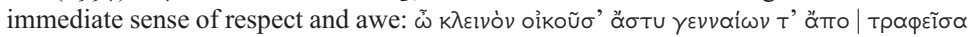

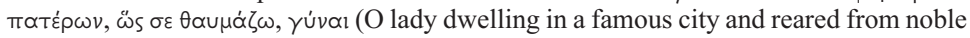
ancestors, how I wonder at you!).

40 Cf. Giraud (I987) 84 and Zeitlin (I989) I 44 on the strong connections between Ion and birds in this play; see also Hoffer (I996) 297-9, Griffiths (2017) 238 and McPhee (20 I 7 ) $475^{-89}$ on the significance of birds and bird imagery throughout the play.

4I See Lee (I997) I74 on the Ion's multiple 'surprising intrusions'. 
end of the play where we find bird imagery returning most explicitly. The unwanted avian incursions into the temple precinct during Ion's temple-cleaning monody prefigure the paradoxically welcome intrusion of a dove, which saves Ion from certain death by preventing him from drinking poison at the play's climax ( I 202-6):

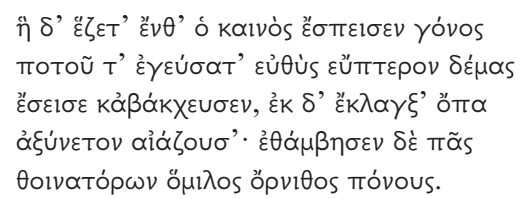

But the bird landed where the new son had made a libation and tasted the drink: immediately it shook its fair-winged body and became frenzied like a Bacchant, and wailing, it screeched out a voice hard to interpret. And the whole gathering of feasters wondered at the sufferings of the bird.

The wonder of the assembled crowd at the monstrous images of Ion's tent is transmuted into astonishment $(\theta \alpha \dot{\alpha} \mu \beta \eta \sigma \varepsilon \nu$ $\delta \dot{\varepsilon} \pi \widetilde{\alpha} s$, I 205) at the monstrous fate which overcomes the bird, a symbol of Ion himself - though the fact that the recognition of mother and son succeeds without disaster soon after this moment soon becomes the most wondrous aspect of the play as a whole.

Just as in the IT, in the Ion too Euripides inverts the antithesis between near and far to establish the wonder of the familiar as a category of experience which forces his characters - and the audience - to question their most basic and deeply held assumptions. The displacement of the familiar into unusual contexts can also have new and unexpected effects. This idea, namely that wonder can be something found near at hand, becomes particularly important when the concept of recognition is considered. Whereas the astonishment provoked by the distant often entails complete ignorance of the object provoking wonder, the wonder of the familiar often involves a recovery of knowledge, a recognition that in itself is able to provoke an often disconcerting sense of thauma due to the uncanny closeness of the object of wonder to its subject. Rather than associating thauma with the unusual or the unfamiliar, in this play we see a radically different 


\subsection{Marvels at the Centre}

conception of what the wondrous might be: the ordinary as well as the extraordinary, the familiar as well as the unfamiliar. This type of thauma, based on the unexpected mutual entwining of near and far, holds just as much potential to surprise, delight, or disturb, as the next chapter will demonstrate. ${ }^{42}$

42 Cf. Daston and Park (I998) 3I I and Kareem (20I4) 55 on the importance of viewing wonder not only as something associated with the unfamiliar, but as (in Kareem's words) 'a category within the aesthetics of ordinary experiences'. 